\title{
Silové schopnosti a jejich vliv na sportovní výkon v lezení
}

\section{Strength Abilities and Their Influence on Sports Performance in Climbing}

\author{
Jan Došla, Jan Meško \\ Fakulta sportovních studii, Masarykova univerzita Brno
}

\begin{abstract}
Abstrakt
Článek pojednává o vlivu silových schopností na výkon v lezení. Silové schopnosti jsme měřili pomocí dvou motorických testů. Jednalo se o test ruční dynamometrie a test výdrže ve shybu. Dále jsme u testovaných osob měřili základní antropometrické veličiny - výšku, hmotnost, podíl tělesného tuku a somatotyp. $V$ rámci výzkumu jsme vyhodnotili 46 osob, které jsme rozdělili do tří skupin na výkonnostní lezce, rekreační lezce a nelezce. Všechny testované osoby byly muži. Jednotlivé skupiny jsme pak porovnávali mezi sebou. Statisticky významné rozdíly jsme našli v parametrech "výdrž ve shybu" a „podíl tělesného tuku“. Rozdíly ostatních sledovaných parametrů nebyly při porovnání jednotlivých skupin statisticky významné.
\end{abstract}

\begin{abstract}
The article discusses the impact of strength abilities on performance in climbing. Strength abilities were measured using two motor tests. It was a test of dynamometry and pull-up hang test. Furthermore, anthropometric variables, which include height, weight and body fat percentage, have been measured. During the research a total of 46 persons have been measured; these were divided into three groups performance climbers, recreational climbers and non-climbers. Only men have been included in the test. The groups have been compared to each other with statistically significant differences being found in parameters "pull-up hang" and "body fat percentage". No statistically significant differences between other parameters have been found.
\end{abstract}

Klíčová slova: lezení, silové schopnosti, dynamometrie, výdrž ve shybu, somatotyp, tělesný tuk.

Key words: climbing, strength abilities dynamometry, pull-up hang, somatotype, body fat.

\section{ÚVOD}

Sportovní lezení je dynamicky se rozvíjející oblast sportu, které se věnuje stále více lidí (Mermier, Janot, Parker, \& Swan 2000; Panáčková, Baláš, \& Bunc, 2012; Schlegel, Fialová, Ulrichová, \& Frainšic, 2012; Vomáčko \& Boštíková, 2008). Důkazem je stále rostoucí počet členů lezeckých organizací, zvyšující se počet lezeckých stěn a také rostoucí koncentrace lezců ve skalních oblastech. Společně s rostoucí oblibou sportovního lezení roste i potřeba hlubšího poznání lezeckého výkonu. K rozpoznání lezeckého talentu či k vyvinutí účinnějších tréninkových metod je nejprve zapotřebí určit, které dílčí komponenty lezeckého výkonu jsou kličové a které jsou méně důležité. V současnosti již existuje řada odborných prací na toto téma (Baláš, Strejcová, \& Hrdličková, 2008; Grant, Hynes, Whittaker, \& Aitchison, 1996; Grant, Hasler, Davies, Aitchison, Wilson, \& Whittaker, 2001; Mermier, Janot, Parker, \& Swan, 2000; Vomáčko, 2009), avšak jejich společnou nevýhodou je to, že se věnují pouze omezenému vzorku lezecké populace. Výsledky měření se tak nedají zcela zobecnit, což otevírá prostor pro nová měření, která mají za úkol ověřit platnost předešlých šetření.

Z kondičních faktorů mají určitě největší význam silové schopnosti. Sportovní lezení klade na silové schopnosti nemalé nároky. Dle Rotmana (cit. podle Heller, 1996) je při lezení důležitá maximální a vytrvalostní síla paží a horní poloviny těla a maximální statická síla flexorů prstů. Spe- 
cifické metody rozvoje silových schopností pro účely sportovního lezení popisuje Tefelner (2012). Doporučuje posilování prostřednictvím vlastního lezení, a také prostřednictvím boulderingu. Dále doporučuje dynamická i statická cvičení na hrazdě, statické visy na lištách nebo na chytech různých tvarů, cvičení na žebříku a šplh na laně, dynamické cvičení na speciální lištové desce campus boardu, a další cvičení např. v posilovně nebo pomocí méně tradičních cvičebních pomůcek (TRX, system board, apod.). V jeho doporučeních lze nejčastěji identifikovat různé modifikace silového a objemového, př́padně izometrického tréninku. Bouldering a lezení na umělé stěně je podle něho výhodné zejména proto, že se jedná o cvičení ve specifických podmínkách, které nejlépe odpovídá zatížení při soutěži nebo při vážném pokusu o přelez na výkonnostní úrovni. Zároveň s posílením nejdůležitějších svalových skupin dochází i k tréninku lezecké techniky. Z některých dosavadních výzkumů můžeme uvést následující. Grant, Hynes, Whittaker, \& Aitchison (1996) pozorovali u souboru deseti výkonnostních lezců (výkonnost 6+ UIAA a vyšší), deseti rekreačních lezců a deseti nelezců signifikantní meziskupinové rozdíly v hodnotách maximální statické síly stisku levé ruky, síly stisku palce proti ukazováku u obou rukou a síly dvou i čtyř prstů u obou rukou v otevřeném úchopu. Dále našli významné rozdíly u proměnných „výdrž ve shybu“, „opakované shyby“. Síla břišních svalů měřená opakovaným sed-lehem nevykazovala statisticky významné meziskupinové rozdíly. K podobným výsledkům došli i Baláš, Strejcová \& Hrdličková (2008), kteří porovnávali skupiny výkonnostních a rekreačních lezců a lezkyň. Konstatovali, že výkonnostní lezci/lezkyně se vyznačují větší absolutní i relativní silou stisku ruky a delší výdrží ve shybu. V další studii Vomáčko, Baláš, \& Jindra (2011) našli taktéž významný vztah mezi lezeckým výkonem (OS i RP) a testy „výdrž ve shybu“ a „ruční dynamometrie“ (pro dominantní ruku). Dále se silovými dispozicemi lezců hlouběji zabývali MacLeod, Sutherland, Buntin, Whittaker, Aitchison, Watts, ... \& Grant (2007). Zjistili signifikantní rozdíly mezi skupinami výkonnostních lezců a nelezců v maximální a relativní volní kontrakci čtyřprstů při otevřeném úchopu (měřeno speciálně konstruovaným aparátem). Výsledky některých předchozích výzkumů shrnujeme v tabulkách č. 1 a 2.

Souhrnně můžeme konstatovat, že lezecký výkon je závislý z velké části na silových schopnostech. Výkonnostní lezci se vyznačují lepší úrovní vytrvalostní síly pletence ramenního, maximální i relativní silou flexorů prstů a také jejich vytrvalostí vztaženou na vyvinutou sílu, která je determinována lepší reoxygenací svalů předloktí.

Tabulka 1: Výsledky nejčastěji používaných testů silových schopností - muži (u hodnot označených * byla měřena pravá ruka, u ostatních dominantní ruka)

\begin{tabular}{|l|c|c|c|c|c|c|}
\hline & $\mathbf{N}$ & $\begin{array}{c}\text { Výkonnost } \\
\text { (UIAA) }\end{array}$ & $\begin{array}{c}\text { Ruční } \\
\text { dynamometrie } \\
\text { (N) }\end{array}$ & $\begin{array}{c}\text { Relativní síla } \\
\text { stisku } \\
\text { (N/kg TH) }\end{array}$ & $\begin{array}{c}\text { Výdrž } \\
\text { ve shybu (s) }\end{array}$ & $\begin{array}{c}\text { Shyby } \\
\text { (počet) }\end{array}$ \\
\hline Baláš et al. (2012) & 11 & $9+$ až $11+$ & & $7,9 \pm 0,7$ & $84,5 \pm 23,2$ & \\
\hline Šefl (2009) & 12 & 7 až 10 & $502 \pm 72^{*}$ & & $64,9 \pm 22,6$ & $18,7 \pm 6,4$ \\
\hline Mermier et al. (2000) & 24 & $6-$ až $10-$ & & $6,5 \pm 1,4$ & $51,8 \pm 14,6$ & \\
\hline Baláš et al. (2012) & 38 & $7+$ až 9 & & $7,2 \pm 0,9$ & $64,2 \pm 19,1$ & \\
\hline Baláš et al. (2008) & 12 & 7 až 9 & $532 \pm 74$ & $7,2 \pm 1,2$ & $58,0 \pm 17,4$ & \\
\hline Grant et al. (1996) & 10 & $>6+$ & $532 \pm 23^{*}$ & & $53,1 \pm 13,2$ & $16,2 \pm 7,2$ \\
\hline Grant et al. (1996) & 10 & $<6+$ & $472 \pm 23^{*}$ & & $31,4 \pm 9,0$ & $3,0 \pm 9,0$ \\
\hline Baláš et al. (2008) & 33 & 3 až 6 & $453 \pm 86$ & $5,8 \pm 0,1$ & $34,9 \pm 21,3$ & \\
\hline
\end{tabular}


Tabulka 2: Výsledky nejčastěji používaných testů silových schopností - ženy (u hodnot označených * byla měřena pravá ruka, u ostatních dominantní ruka)

\begin{tabular}{|l|c|c|c|c|c|c|}
\hline & $\mathbf{N}$ & $\begin{array}{c}\text { Výkonnost } \\
\text { (UIAA) }\end{array}$ & $\begin{array}{c}\text { Ruční } \\
\text { dynamometrie } \\
\text { (N) }\end{array}$ & $\begin{array}{c}\text { Relativní síla } \\
\text { stisku } \\
\text { (N/kg TH) }\end{array}$ & $\begin{array}{c}\text { Výdrž } \\
\text { ve shybu (s) }\end{array}$ & $\begin{array}{c}\text { Shyby } \\
\text { (počet) }\end{array}$ \\
\hline Baláš et al. (2012) & 3 & $9+$ až $11+$ & & $7,2 \pm 0,7$ & $68.9 \pm 6.4$ & \\
\hline Baláš et al. (2012) & 12 & $7+$ až 9 & & $6,0 \pm 0,6$ & $59.4 \pm 12.4$ & \\
\hline Baláš et al. (2008) & 3 & 7 až 9 & $321 \pm 57$ & $5,5 \pm 0,6$ & $44,7 \pm 22,2$ & \\
\hline Mermier et al. (2000) & 20 & $5-$ až $9-$ & & $4,9 \pm 1,0$ & $25,1 \pm 14,4$ & \\
\hline Grant et al. (2001) & 10 & $>5+$ & $338 \pm 12^{*}$ & & $27,5 \pm 19,4$ & $2,1 \pm 3,0$ \\
\hline Baláš et al. (2008) & 20 & 3 až 6 & $275 \pm 56$ & $4,4 \pm 0,8$ & $14,9 \pm 14,8$ & \\
\hline Grant et al. (2001) & 10 & $<5+$ & $289 \pm 10^{*}$ & & $13,7 \pm 8,1$ & $0,2 \pm 0,7$ \\
\hline
\end{tabular}

\section{METODIKA}

V našem výzkumu jsme sledovali silové schopnosti lezců a nelezců. Výzkumu se zúčastnilo 46 mužů ve věku 18 až 40 let. TO byli vybráni metodou stratifikovaného výběru. Rozděleny byly podle lezecké výkonnosti do tří podskupin - výkonnostní lezci, rekreační lezci a nelezci. Do výkonnostní kategorie jsme zařadili lezce, kteří v posledních deseti měsících vylezli cestu minimální obtížnosti 7 UIAA stylem RP nebo PP. Tuto hodnotu jsme stanovili na základě teorie Baláše, Strejcové, \& Hrdličkové (2008, str. 105), podle nichž si „posun od šestého stupně k sedmému žádá soustředěnějši specifický lezecký trénink. " Do kategorie rekreačních lezců byli zařazeni ti, jejichž lezecká praxe je delší než jeden rok, avšak nejsou schopni vylézt cestu o obtížnosti vyšší než 7UIAA stylem RP nebo PP. Do poslední kategorie byli zařazeni fyzicky aktivní (resp. sportující) jedinci, kteří se pravidelně nevěnují žádnému druhu lezení.

Co se týče prvních dvou kategorií, jednalo se o lezce navštěvující lezecké stěny v Brně, Broumově a Polici nad Metují. Probandi do kategorie nelezců byli získáváni především z řad studentů PedF a FSpS MU. Všichni účastníci byli nejprve zpraveni o metodách a cílech výzkumu a měření se zúčastnili dobrovolně. Konkrétní informace o výzkumném souboru (průměrný věk, délka lezecké praxe a obtížnost nejtěžší přelezené cesty) jsou přehledně uvedeny v tabulce č. 3.

Tabulka 3: Základní údaje o TO (průměr \pm směrodatná odchylka)

\begin{tabular}{|l|c|c|c|}
\hline & $\begin{array}{c}\text { Výkonnostní lezci } \\
(\mathbf{n}=\mathbf{1 6})\end{array}$ & $\begin{array}{c}\text { Rekreační lezci } \\
(\mathbf{n}=\mathbf{1 5})\end{array}$ & $\begin{array}{c}\text { Nelezci } \\
(\mathbf{n}=\mathbf{1 5})\end{array}$ \\
\hline Věk (roky) & $29,1 \pm 7,1$ & $25,5 \pm 4,9$ & $23,7 \pm 1,6$ \\
\hline Délka lezecké praxe (v letech) & $7,9 \pm 7,5$ & $5,6 \pm 5,2$ & - \\
\hline Četnost lezení (týdně) & $2,0 \pm 0,7$ & $1,4 \pm 0,6$ & - \\
\hline Maximální výkon Top Rope & 8 UIAA & $6 / 6+$ UIAA & - \\
\hline Maximální výkon RP (PP) & $8-/ 8$ UIAA & $6-/ 6$ UIAA & - \\
\hline Četnost dalších sport. aktivit (týdně) & $1,9 \pm 2,4$ & $2,6 \pm 2,6$ & $3,8 \pm 1,8$ \\
\hline
\end{tabular}

Základní údaje o testovaných osobách byly získávány prostřednictvím krátkého sedmibodového nestandardizovaného dotazníku. Byl zjištován věk, délka lezecké praxe, četnost lezení, zaměření v rámci horolezeckých disciplín, obtížnost nejtěžší cesty přelezené stylem Top Rope a Red Point (resp. Pink Point) v posledních deseti měsících a druh a četnost dalších sportovních aktivit.

Pro testování silových schopností jsme vybrali dva testy, test ruční dynamometrie a test výdrže ve shybu. Pomocí ruční dynamometrie jsme zjištovali maximální sílu stisku ruky (maximální statickou sílu flexorů prstů). Pro měření jsme využili digitální analyzátor MIE (Medical Research 
Ltd.). TO uchopí dynamometr na vyznačeném místě a svěsí paži podél těla. Během stisku není dovoleno opírat se měřenou rukou o stehno nebo jiný předmět. Po zahájení pokusu TO plynule zvyšuje svoje úsilí do subjektivního maxima. Testovaná osoba prováděla vždy dva pokusy na pravou i levou ruku, počítal se lepší z obou pokusů. Pomocí motorického testu „výdrž ve shybu“ jsme měřili úroveň vytrvalostní statické síly flexorů paží a pletence ramenního. TO pomůžeme zaujmout základní pozici - shyb na doskočné nebo dosažné hrazdě. Žerd’ držíme nadhmatem v šírí ramen, brada je nad žerdí. Ručními stopkami měříme výdrž s přesností na $0,1 \mathrm{~s}$. Pokus končí, pokud se TO dotkne bradou žerdi, nebo se brada dostane pod její úroveň (Pavlík, Sebera, Stochl, Vespalec, \& Zvonař, 2010).

Pro statistické zpracování numerických dat, získaných výše uvedenými metodami, jsme použili programy MS Excel 2010 a STATISTICA 12. Nejprve jsme provedli základní deskriptivní statistiku s určením průměrů a směrodatných odchylek jednotlivých proměnných, a to pro každou skupinu zvlášt. Dále jsme pro porovnání výsledků všech tř́ skupin použili jednofaktorovou analýzu rozptylu (ANOVA) při hladině statistické významnosti $\alpha=0,05$. Abychom zabezpečili základní předpoklad pro parametrickou ANOVU, provedli jsme nejprve Leveneův test homogenity rozptylu. U proměnných, které vykazovaly nehomogenní rozptyl, jsme použili neparametrický Kruskal-Wallisův test. Proměnné, které vykazovaly signifikantní meziskupinový rozdíl, jsme dále podrobili vícenásobnému porovnání pomocí Bonferroniho post-hoc testu (Zvárová, 1998).

Protože pro výpočet p-hodnot a celkově pro stanovení statistické významnosti hraje důležitou roli rozsah analyzovaného souboru, rozhodli jsme se doplnit práci o posouzení hladiny věcné významnosti (effect size) pomocí koeficientů effect size asociovaným ke konkrétním typům statistických testů. Jedná se o koeficient $\omega^{2}$, který lze vypočítat z hodnoty testového kritéria analýzy rozptylu. U proměnných, u kterých zjistíme střední nebo vysoký efekt, dále použijeme Cohenův koeficient $\mathrm{d}$, který porovnává dvojice průměrů vzhledem ke směrodatným odchylkám a rozsahu souboru (Sigmund \& Sigmundová, 2010). Z výsledků pak bude patrné, mezi kterými skupinami existuje věcně významný rozdíl.

\section{VÝSLEDKY}

Vedle motorických testů jsme také u testovaných osob provedli některá základní antropometrická měření - tělesná výška, tělesná hmotnost a podíl tělesného tuku. Všechny naměřené hodnoty uvádíme v tabulce č. 4.

Tabulka 4: Výsledky motorických testů a vybrané antropometrické parametry (průměr \pm směrodatná odchylka)

\begin{tabular}{|l|c|c|c|}
\hline & $\begin{array}{c}\text { Výkonnostní lezci } \\
(\mathbf{n = ~ 1 6 )}\end{array}$ & $\begin{array}{c}\text { Rekreační lezci } \\
(\mathbf{n}=\mathbf{1 5})\end{array}$ & $\begin{array}{c}\text { Nelezci } \\
(\mathbf{n}=\mathbf{1 5})\end{array}$ \\
\hline Ruční dynamometrie - pravá (N) & $533,4 \pm 58,3$ & $523,7 \pm 78,6$ & $534,5 \pm 91,6$ \\
\hline Ruční dynamometrie - levá (N) & $505,8 \pm 70,4$ & $484,0 \pm 64,9$ & $499,9 \pm 105,3$ \\
\hline Relativní síla stisku - pravá (N/kg TH) & $7,48 \pm 1,00$ & $7,10 \pm 0,95$ & $6,79 \pm 1,13$ \\
\hline Relativní síla stisku - levá (N/kg TH) & $7,10 \pm 1,20$ & $6,58 \pm 0,88$ & $6,32 \pm 1,16$ \\
\hline Výdrž ve shybu (s) & $59,4 \pm 17,5$ & $41,1 \pm 11,1$ & $36,2 \pm 11,5$ \\
\hline Tělesná výška (cm) & $179,0 \pm 9,3$ & $179,6 \pm 5,7$ & $182,1 \pm 7,5$ \\
\hline Tělesná hmotnost (kg) & $71,9 \pm 8,1$ & $74,2 \pm 9,4$ & $79,0 \pm 7,5$ \\
\hline Podíl tělesného tuku (\%) & $10,9 \pm 2,9$ & $13,9 \pm 3,8$ & $14,4 \pm 4,5$ \\
\hline
\end{tabular}

Analýzou rozptylu jsme zjistili, že p-hodnoty proměnných podíl tělesného tuku a výdrž ve shybu jsou menší než hladina statistické významnosti $\alpha=0,05$. S 95\% jistotou tedy u těchto proměnných můžeme konstatovat, že výsledky tří sledovaných skupin se statisticky významně liší. Naopak u ostatních proměnných signifikantní rozdíl shledán nebyl (viz tabulka č. 5). 
Tabulka 5: ANOVA, nezávislá proměnná: Skupina, Stupně volnosti: 2 (model), 43 (rezid.)

\begin{tabular}{|l|r|r|r|r|r|c|}
\hline & \multicolumn{1}{|c|}{$\begin{array}{c}\text { SČ } \\
\text { (Model) }\end{array}$} & $\begin{array}{c}\text { PČ } \\
\text { (Model) }\end{array}$ & $\begin{array}{c}\text { SČ } \\
\text { (Rezid.) }\end{array}$ & $\begin{array}{c}\text { PČ } \\
\text { (Rezid.) }\end{array}$ & \multicolumn{1}{c|}{ F } & p \\
\hline Dynamometrie - pravá & 1060,352 & 530,176 & 258266,6 & 6006,200 & 0,08827 & 0,91568 \\
\hline Dynamometrie - levá & 3880,136 & 1940,068 & 293534,7 & 6826,389 & 0,28420 & 0,75402 \\
\hline Relativní síla stisku - pravá & 3,737 & 1,869 & 45,7 & 1,062 & 1,75962 & 0,18428 \\
\hline Relativní síla stisku - levá & 4,923 & 2,462 & 51,0 & 1,185 & 2,07685 & 0,13772 \\
\hline Výdrž ve shybu & 4664,143 & 2332,071 & 8191,2 & 190,493 & 12,24232 & 0,00006 \\
\hline Výška & 83,286 & 41,643 & 2556,1 & 59,443 & 0,70054 & 0,50189 \\
\hline Hmotnost & 397,225 & 198,612 & 3027,6 & 70,409 & 2,82084 & 0,07061 \\
\hline Podíl tělesného tuku & 114,528 & 57,264 & 611,0 & 14,209 & 4,03005 & 0,02488 \\
\hline
\end{tabular}

Proměnné, u kterých byl nalezen signifikantní rozdíl mezi skupinami, jsme navíc otestovali Bonferroniho post-hoc testem. U podílu tělesného tuku jsme zjistili statisticky významný rozdíl pouze mezi výkonnostními lezci a nelezci. U proměnné výdrž ve shybu byl prokázán signifikantní rozdíl jak mezi výkonnostními lezci a nelezci, tak také mezi výkonnostními a rekreačními lezci (tabulky č. 6 a 7).

Tabulka 6: Bonferroniho test, podíl tělesného tuku

\begin{tabular}{|l|c|c|c|}
\hline & Výkonnostní & Rekreační & Nelezec \\
\hline Výkonnostní & & 0,001872 & 0,000089 \\
\hline Rekreační & 0,001872 & & 1,000000 \\
\hline Nelezec & 0,000089 & 1,000000 & \\
\hline
\end{tabular}

Tabulka 7: Bonferroniho test, výdrž ve shybu

\begin{tabular}{|l|c|c|c|}
\hline & Výkonnostní & Rekreační & Nelezec \\
\hline Výkonnostní & & 0,091749 & 0,036969 \\
\hline Rekreační & 0,091749 & & 1,000000 \\
\hline Nelezec & 0,036969 & 1,000000 & \\
\hline
\end{tabular}

V tabulce č. 8 jsme tučně zvýraznili hodnoty koeficientů effect size, které vykazují velký nebo střední efekt. Proměnné, u kterých byl zjišsěn věcně významný rozdíl mezi skupinami, jsme dále podrobili vícenásobnému porovnání pomocí výpočtu Cohenova koeficientu d. Výsledky, včetně zvýraznění velkých a středních efektů, uvádíme v tabulce č. 9.

Tabulka 8: Hodnoty koeficientů effect size $\omega^{2}$ (tučně jsou označeny hodnoty odpovídající velkému efektu, kurzívou pak hodnoty odpovídající střednímu efektu)

\begin{tabular}{|l|c|}
\hline & $\boldsymbol{\omega}^{2}$ \\
\hline Dynamometrie - pravá & $-0,04$ \\
\hline Dynamometrie - levá & $-0,03$ \\
\hline Relativní síla stisku - pravá & 0,03 \\
\hline Relativní síla stisku - levá & 0,04 \\
\hline Výdrž ve shybu & $\mathbf{0 , 3 3}$ \\
\hline Tělesná výška & $-0,01$ \\
\hline Tělesná hmotnost & 0,07 \\
\hline Podíl tělesného tuku & 0,12 \\
\hline
\end{tabular}


Tabulka 9: Hodnoty koeficientu d pro vícenásobné porovnání (tučně jsou označeny hodnoty odpovídající velkému efektu, kurzívou pak hodnoty odpovídající střednímu efektu)

\begin{tabular}{|l|c|c|c|}
\hline & výkonnostní vs. rekreační & výkonnostní vs. nelezci & rekreační vs. nelezci \\
\hline Výdrž ve shybu & $\mathbf{1 , 2 7}$ & $\mathbf{1 , 5 9}$ & 0,44 \\
\hline Tělesná hmotnost & $-0,25$ & $\mathbf{- 0 , 9 1}$ & $-0,57$ \\
\hline Podíl tělesného tuku & $\mathbf{- 0 , 8 1}$ & $\mathbf{- 0 , 8 5}$ & $-0,12$ \\
\hline
\end{tabular}

Věcně významný rozdíl byl nalezen u proměnných „výdrž ve shybu“, „tělesná hmotnost“ a „podíl tělesného tuku“. Nejčastěji šlo o rozdíl mezi výkonnostními lezci a nelezci, nejmenší rozdíl byl pozorován mezi rekreačními lezci a nelezci.

Na základě analýzy věcné významnosti tedy byly zjištěny meziskupinové rozdíly v hodnotách podílu tělesného tuku, hmotnosti a ve výsledcích motorického testu výdrž ve shybu. Analýza statistické významnosti pak potvrdila meziskupinový rozdíl v hodnotách výdrže ve shybu a podílu tělesného tuku. U sporných proměnných se přikláníme k výsledkům věcné významnosti. Pro lepší představu o rozdílech mezi skupinami dále přikládáme krabicové grafy vybraných proměnných (obrázky č. 1 a 2).

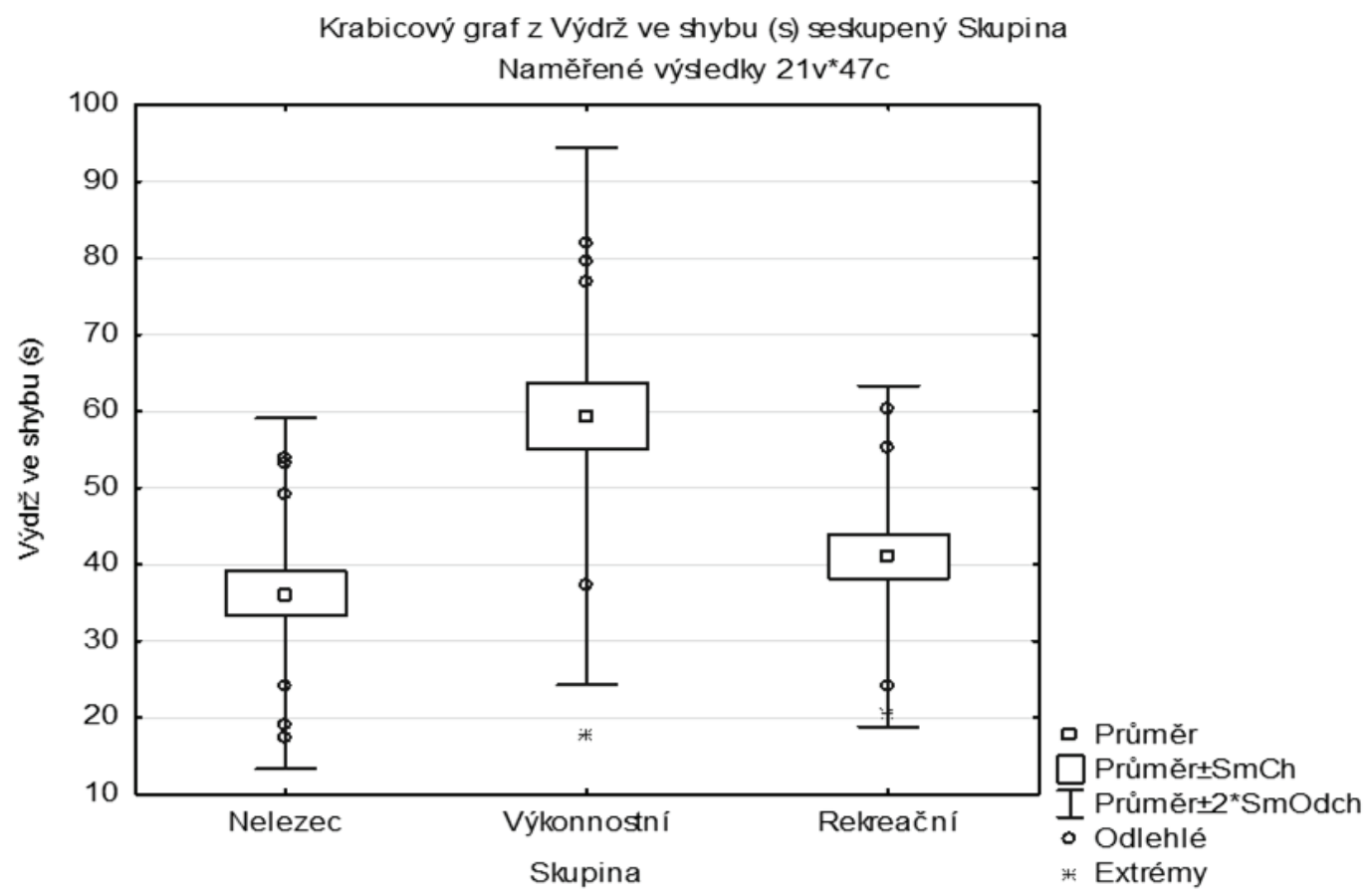

Obr. 1: Krabicový graf proměnné „výdrž ve shybu“ 


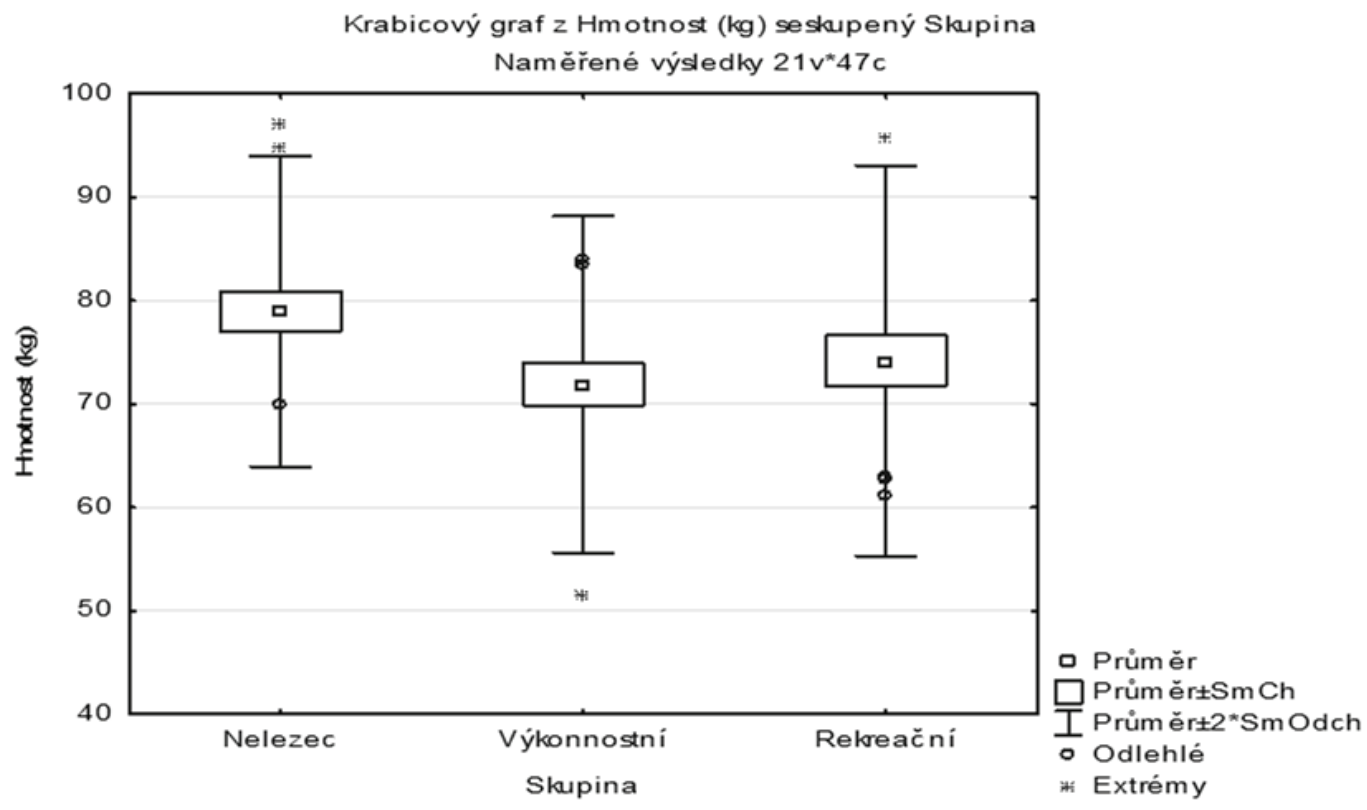

Obr. 2: Krabicový graf proměnné „tělesná hmotnost“

\section{DISKUSE}

V našem výzkumu jsme testovali 46 osob rozdělených dle lezecké výkonnosti na výkonnostní lezce, rekreační lezce a nelezce. Testování se také zúčastnil nejlepší světový lezec Adam Ondra, dvojnásobný mistr světa z roku 2014, kterého jsme z pochopitelných důvodů nezařadili do žádné ze skupin, ale jeho výsledky přinášíme $\mathrm{v}$ diskusi.

U výsledků ruční dynamometrie nebyly shledány rozdíly mezi výkonnostními skupinami v úrovni maximální statické síly stisku ruky ani statisticky, ani věcně. Nelze tedy potvrdit závěry Baláše, Strejcové, \& Hrdličkové (2008), Šefla (2009), ani Vomáčka, Baláše, \& Jindry (2011), že výkonnostní lezci disponují větší silou stisku. Určité rozdíly mezi skupinami jsme našli po přepočtu na $\mathrm{kg}$ tělesné hmotnosti (výkonnostní lezci: 7,48 N/kg; rekreační lezci: 7,10 N/kg; nelezci: 6,79 N/kg výsledky pravé ruky). Vysoké úrovně relativní síly stisku ruky dosáhl také Ondra $(9,17 \mathrm{~N} / \mathrm{kg}-$ pravá). Jak již ale bylo zmíněno, tato tendence nebyla potvrzena ani statistickou ani věcnou analýzou dat.

Největší rozdíly mezi třemi sledovanými skupinami vykazoval motorický test výdrž ve shybu nadhmatem. Výkonnostní lezci v našem měření dosáhli průměrné výdrže 59,4 s, rekreační lezci 41,1 s a nelezci 36,2 s, což lze porovnat se studiemi Granta, Hynese, Whittakera, \& Aitchisona (1996) a Baláše, Strejcové, \& Hrdličkové (2008), kteří u výkonnostních lezců dospěli k podobným hodnotám. Adam Ondra dosáhl výdrže 89,97 s a byl v našem měření nejlepší. Statisticky i věcně významné rozdíly byly nalezeny mezi výkonnostními a rekreačními lezci $(p=0,002)$ a mezi výkonnostními lezci a nelezci $(\mathrm{p}=0,00009)$. Výsledky ukazují, že pro sportovní lezení je vytrvalostní statická síla pletence ramenního velmi důležitá. Vomáčko, Baláš, \& Jindra (2011) ji dokonce považují za důležitý prediktor lezeckého výkonu. Dle těchto autorů je předpokladem vysoké lezecké výkonnosti výdrž o délce trvání alespoň $60 \mathrm{~s}$. V našem měření ovšem pět ze šestnácti výkonnostních lezců této hodnoty nedosáhlo. Domníváme se, že handicap menší vytrvalostní síly lze na této výkonnostní úrovni kompenzovat dobrou lezeckou technikou a výběrem vhodných cest, zejména položených a kolmých. 
Co se týká základních antropometrických parametrů, tedy tělesné výšky a hmotnosti, naše výsledky se podobaly jiným studiím. Průměrná výška výkonnostních lezců $(179,0 \pm 9,3 \mathrm{~cm})$ byla prakticky stejná také u lezců rekreačních $(179,6 \pm 5,7 \mathrm{~cm})$. Nelezci byli v průměru pouze o tři, resp. o dva a půl centimetru vyšší. Ani Adam Ondra svojí výškou nijak nevyniká $(183,5 \mathrm{~cm})$. Teoreticky by vyšší lezci mohli mít při lezení větší dosah, ovšem nevýhodou by zase byla vyšší tělesná hmotnost a zřejmě i nevýhodný pákový mechanismus horních končetin. Vyšší dosah paží tak může znamenat výhodu pouze v některých dílčích lezeckých krocích, nikoliv v celém spektru lezeckých cest.

Hodnota průměrné tělesné hmotnosti se mezi jednotlivými skupinami lišila. Výkonnostní lezci (71,9 kg), měli v průměru nižší tělesnou hmotnost než rekreační lezci $(74,2 \mathrm{~kg})$ a nelezci $(79,0 \mathrm{~kg})$. Tělesná hmotnost Adama Ondry byla 66,2 kg. Rozdíl mezi první a třetí skupinou byl shledán věcně významným. Je pochopitelné, že v pohybové aktivitě vyznačující se opakovaným překonáváním gravitační síly bude nízká tělesná hmotnost výhodou. Důležité je ovšem zachovat dostatečně velký podíl aktivní tělesné hmoty. Dalším významným parametrem je podíl tělesného tuku, pro jehož změření jsme zvolili metodiku dle Pařízkové. U výkonnostních lezců byl shledán průměrný podíl tuku 10,9 2,9\% (Ondra 6,6 \%), u rekreačních lezců 13,9 $\pm 3,8 \%$ a u nelezců $14,4 \pm 4,5 \%$. Rozdíl mezi výkonnostními lezci a nelezci byl shledán statisticky i věcně významným ( $p=0,037)$, rozdíl mezi výkonnostními a rekreačními lezci byl shledán „pouze“ věcně významným. Ukazuje se, že podíl tělesného tuku směrem k vyšší výkonnosti klesá. K podobným závěrům došli i MacLeod, Sutherland, Buntin, Whittaker, Aitchison, Watts, ... \& Grant (2007), kteří zjistili signifikantní rozdíly v podílu tělesného tuku mezi skupinami lezců a nelezců. Významný vztah mezi lezeckou výkonností a podílem tělesného tuku také uvádí ve své studii Baláš, Strejcová, \& Hrdličková (2008).

\section{ZÁVĚRY}

Na začátku této práce jsme si položili za cíl poodhalit vztah mezi lezeckou výkonností a silovými schopnostmi. Dále jsme také sledovali vybrané antropometrické parametry. Výsledky měření ukazují, že výkonnostní lezci jsou spíše středně vysocí $(179 \pm 9,3 \mathrm{~cm}) \mathrm{s}$ menší hodnotou tělesné hmotnosti $(71,2 \pm 8,1 \mathrm{~kg})$ a menším podílem tělesného tuku $(10,9 \pm 2,9 \%)$. Tyto výsledky mohou zohlednit např. trenéři a instruktoři při výběru lezeckých talentů nebo samotní sportovci př̀i hledání nové pohybové aktivity, která by jim byla šitá přímo na míru. V rámci vrcholového lezení, jak naznačují i výsledky Adama Ondry, je nízká hmotnost a zejména nízké procento tělesného tuku důležitou determinantou lezeckého výkonu.

Z výsledků motorického testování jsme zjistili, že výkonnostní lezci se vyznačují větší úrovní statické vytrvalostní síly svalů podílejících se na extenzi v ramenním kloubu (motorický test „výdrž ve shybu"). Naopak v úrovni maximální i relativní síly stisku ruky se výkonnostní lezci oproti zbylým dvěma skupinám téměř nelišili. Co se týče maximální síly stisku ruky, nemusí být tento parametr tolik významný, jako např. vytrvalostní síla stisku, nebo rychlost reoxygenace flexorů prstů, jak už ostatně dokázali MacLeod, Sutherland, Buntin, Whittaker, Aitchison, Watts, ... \& Grant (2007).

Na základě výsledků našeho testování bychom mohli doporučit specifický trénink na lezecké či boulderové stěně, pomocí kterého lze rozvíjet potřebné kondiční schopnosti a zároveň se také zlepšovat $\mathrm{v}$ technice lezeckého pohybu. Dále můžeme doporučit nespecifické tréninkové metody, které by byly zaměřené na sílu horních končetin. $Z$ výběru možných cvičení se nám zdá vhodné zařadit do tréninku shyby na hrazdě nadhmatem, šplh na laně nebo ručkování po šikmém žebříku. Vzhledem k tomu, že se při lezení průběžně střídá dynamický pohyb se statickými výdržemi, je dobré aplikovat při tréninku intermediární metodu rozvoje silových schopností. $Z$ dalších metod bychom mohli doporučit silově-vytrvalostní trénink pro rozvoj vytrvalostní dynamické síly a silový trénink pro zlepšení vnitrosvalové koordinace. 


\section{Literatura}

Baláš, J., Pecha, O., Martin, A. J., \& Cochrane, D. (2012). Hand arm strength and endurance as predictors of climbing performance. European Journal of Sport Science. 12(1), 16-25

Baláš, J., Strejcová, B., \& Hrdličková, A. (2008). Srovnání úrovně svalové síly a tělesného složení u rekreačních a výkonnostních lezců. Česká kinantropologie, 12(3), 104-114

Grant, S., Hasler, T., Davies, C., Aitchison, T. C., Wilson, J., \& Whittaker, A. (2001). A comparison of the anthropometric, strength, endurance and flexibility characteristics of female elite and recreational climbers and nonclimbers. Journal of Sports Sciences, 19(7), 499-505

Grant, S., Hynes, V., Whittaker, A., \& Aitchison, T. C. (1996). Anthropometric, strength, endurance and flexibility characteristics of elite and recreational climbers. Journal of Sports Sciences, 14(4), 301-309

Heller, J. (1996). Fyziologie tělesné zátěže Il. Speciální část, 3. díl. Praha: Karolinum

MacLeod, D., Sutherland, D. L., Buntin, L., Whittaker, A., Aitchison, T., Watt, I., Bradley, J., \& Grant, S. (2007). Physiological determinants of climbing-specific finger endurance and sport rock climbing performance. Journal of Sports Sciences. 25(12), 1433-1443

Mermier, C. M., Janot, J. M., Parker, D. L., \& Swan, J. G. (2000). Physiological and anthropometric determinants of sport climbing performance. British Journal of Sports Medicine, 34(5), 359-365

Panáčková, M., Baláš, J., \& Bunc, V. (2012). Vliv profilu stěny a rychlosti lezení na energetickou náročnost lezení u skupiny rekreačních a výkonnostních lezců. Česká kinantropologie, 16(2), 124-132

Pavlík, J., Sebera, M., Stochl, J., Vespalec, T., \& Zvonař, M. (2010). Vybrané kapitoly z antropomotoriky. Brno: MU FSpS

Schlegel, P., Fialová, L., Ulrichová, T., \& Frainšic, M. (2012). Rozvoj vybraných motorických schopností u dětí školního věku prostrednictvím sportovního lezení. Česká kinantropologie, 16(3), 56-62

Sigmundová, D. \& Sigmund, E. (2010). Statistická a věcná významnost a použití koeficientů velikosti účinku při hodnocení dat o pohybové aktivitě. Olomouc: FTK UP

Šefl, J. (2009). Posouzení závislosti fyzické zdatnosti a lezeckého výkonu ve sportovním lezení. Diplomová práce. Praha: UK FTVS

Tefelner, R. (2012). Trénink sportovního lezce Il. Czech republic: Rock Art Studio

Vomáčko, L. (2009). Ke struktuře výkonu ve sportovním lezenív souvislosti s obecnými a speciálními testy pohybové výkonnosti a osobnostního profilu lezce. Disertační práce. Praha: UK FTVS

Vomáčko, L., Baláš, J., \& Jindra, M. (2011). Vybrané kondiční testy a jejich vztah k výkonu ve sportovním lezení. Studia sportiva, 5(1), 105-116

Vomáčko, L. \& Boštíková, S. (2008). Lezení na umělých stěnách. Praha: Grada

Zvárová, J. (1998). Základy statistiky pro biomedicínské obory. Praha: Karolinum 